УДК 547.913:582.477

\title{
КОМПОНЕНТНЫЙ СОСТАВ ЭФИРНОГО МАСЛА МОЖЖЕВЕЛЬНИКА ОБЫКНОВЕННОГО (JUNIPERUS COMMUNIS L.) ПОД ПОЛОГОМ ЕЛОВОГО ДРЕВОСТОЯ НА ЕВРОПЕЙСКОМ СЕВЕРО-ВОСТОКЕ россии
}

\author{
(C) Н.В. Герлинг ${ }^{*}$ В.В. Пунегов, И.В. Груздев \\ Институт биологии Коми НЦ УрО РАН, ул. Коммунистическая, 28, ГСП-2, \\ Сыктывкар, Республика Коми, 167982 (Россия), e-mail: Gerling1@rambler.ru
}

\begin{abstract}
Эфирное масло можжевельника обыкновенного, произрастающего под пологом ельника чернично-сфагнового, представляет собой жидкость светло-желтого цвета. Содержание эфирного масла в охвоенном побеге можжевельника обыкновенного составило $0,81 \%$. В эфирном масле идентифицировано 39 компонентов веществ, их массовая доля составляла $86 \%$ полного состава эфирного масла. Из идентифицированных компонентов монотерпены занимали в эфирном масле 90,5\%, сесквитерпены - 0,4\%, спирты - 7,5\% и эфиры - 1,6\%. В составе эфирного масла можжевельника обыкновенного 96 веществ имели концентрацию менее 1\%, 10 веществ - от 1-5\%, четыре вещества - свыше 5\%. Более высокая концентрация отмечена для таких компонентов, как $\alpha$-пинен $-27,2 \%, \beta$-пинен - 22,4\%, 3-карен - 7\% и $\beta$-фелландрен $-5,7 \%$. Компонентный состав эфирного масла можжевельника обыкновенного характеризуется географической изменчивостью. Выход эфирного масла из охвоенных побегов можжевельника имеет близкие значения с выходом эфирного масла сосны (Pinus pumila (Pall.) Regel.) в Хабаровском крае, однако по содержанию фракции монотерпеноидов превосходит сосну, а по фракции сесквитерпеноидов - уступает.
\end{abstract}

Ключевые слова: Juniperus communis, побег, эфирное масло.

\section{Введение}

Род Juniperus (Cupressaceae) включает 68 видов и 36 разновидностей вечнозеленых древесных растений [1]. Можжевельник обыкновенный - единственный вид рода Juniperus, распространенный в Северном и Южном полушариях Земли [1]. По обилию выделяемых бактерицидных эфирных веществ он превосходит все хвойные растения таежной зоны [2]. Основными органами можжевельника, содержащими эфирные масла, являются хвоя, шишкоягоды и древесина [3]. Содержание эфирного масла J. communis ssp. nana в хвое, шишкоягодах и древесине составляло 0,$78 ; 0,70$ и 0,12\% соответственно [4]. Качественный и количественный составы эфирного масла изучены у можжевельника обыкновенного, произрастающего в Северной Греции [5], Италии [6], Литве [7], Швеции [8], Китае [9], Польше [10], Канада [11], Хорватия [12].

Цель настоящей работы заключалась в выявлении качественного и количественного составов эфирного масла, выделяемого из охвоенных побегов можжевельника обыкновенного, произрастающего в подзоне средней тайги.

\section{Экспериментальная часть}

Герлинг Наталья Владимировна - кандидат биологических наук, научный сотрудник, e-mail: Gerling1@rambler.ru

Пунегов Василий Витальевич - кандидат химических наук, старший научный сотрудник, e-mail: punegov@ib.komisc.ru

Груздев Иван Владимирович - кандидат химических наук, доцент, e-mail: gruzdev@ib.komisc.ru
Сбор образцов охвоенных побегов можжевельника обыкновенного проводили в мае 2012 г. в ельнике чернично-сфагновом (62 $16^{\prime} 03^{\prime \prime}$ с.ш. $50^{\circ} 41^{\prime} 07^{\prime \prime}$ в.д.), расположенном в подзоне средней тайги. Эфирное масло выделяли методом гидродистилляции по способу II ГФ СССР (11-е изд.) [13]. Навеску образцов побегов с хвоей в 20 г помещали

\footnotetext{
* Автор, с которым следует вести переписку.
} 
в круглодонную колбу объемом 1 л, снабженную насадкой Клевенджера, и проводили гидродистилляцию в течение 3,5 ч. Эфирное масло экстрагировали из конденсата пентаном (3 мл). Полученный раствор обезвоживали, помещая на 12 ч в морозильную камеру. Пентан отделяли от эфирного масла термостатированием колбы при $+50{ }^{\circ} \mathrm{C}$ на водяной бане. Выход эфирного масла определяли хроматографически. С эфирным маслом в пентане проводили газохроматографический (ГХ) и хромато-масс-спектрометрический (ГХ/MC) анализы. Компонентный состав эфирного масла можжевельника обыкновенного определяли методами ГХ с пламенно-ионизационным детектором (ПИД) и ГХ/МС.

Газохроматографический анализ выполняли на хроматографе «Кристалл 2000М» (Хроматэк, Россия) с пламенно-ионизационным детектором, совмещенным с системой сбора и обработки хроматографической информации «Хроматэк Аналитик 2.5». Идентификацию веществ проводили на хромато-масс-спектрометре TRACE DSQ фирмы Thermo (газовый хроматограф TRACE GC Ultra и масс-спектрометр DSQ) в режиме полного ионного тока (энергия электронов 70 эВ). Условия определения компонентов эфирных масел в обоих методах были одинаковы: программирование температуры термостата колонок $40{ }^{\circ} \mathrm{C}$ (4 мин) $4{ }^{\circ} \mathrm{C} /$ мин $-300{ }^{\circ} \mathrm{C}(10$ мин); кварцевая капиллярная колонка TR-5MS (Thermo) $30 \mathrm{м} \times 0,25$ мм, толщина пленки (полифенилметилсиликон, 5\% фенильных групп) - 0,25 мкм; газ-носитель - гелий (99,99 \%), скорость потока через колонку $-0,6 \mathrm{~cm}^{3} /$ мин, деление потока $-1: 50$; температура испарителя $-280{ }^{\circ} \mathrm{C}$, интерфейса масс-спектрометра $-250^{\circ} \mathrm{C}$, источника ионов $-200{ }^{\circ} \mathrm{C}$, пламенно-ионизационного детектора $265^{\circ} \mathrm{C}$. Интерпретацию масс-спектров проводили с использованием программного обеспечения Xcalibur Data System (ver. 1.4 SR1) и библиотеки масс-спектров NIST 05 (ver. 2.0, 220 тыс. соединений). Количественное содержание компонентов эфирного масла оценивали методом внутренней нормализации, измерения проводили в трехкратной повторности.

\section{Обсуждение результатов}

Эфирное масло можжевельника обыкновенного представляет собой жидкость светло-желтого цвета. Содержание эфирного масла в охвоенном побеге составило $0,81 \pm 0,04 \%$. В эфирном масле можжевельника обыкновенного идентифицировано 39 компонентов из 110 обнаруженных. Массовая доля идентифицированных компонентов эфирного масла составила $86 \%$ (табл. 1). Из идентифицированных компонентов монотерпены занимали $90,5 \%$, сесквитерпены $-0,4 \%$, спирты $-7,5 \%$ и эфиры $-1,6 \%$.

В составе эфирного масла можжевельника обыкновенного 96 веществ имели концентрацию менее $1 \%, 10$ веществ - от 1-5\%, четыре вещества - свыше 5\%. Более высокая концентрация отмечена для таких компонентов, как $\alpha$-пинен $-27,2 \%, \beta$-пинен $-22,4 \%, 3$-карен $-7 \%$ и $\beta$-фелландрен $-5,7 \%$. У J. communis, произрастающего в Швеции, в эфирном масле наибольший процент занимали $\alpha$-пинен $(56,8 \%), \beta$-пинен $(8,9 \%)$, лимонен $(5,1 \%), \delta$-3-карен $(4,7 \%)$ [8], в Северной Греции - $\alpha$-пинен $(41,3 \%)$, сабинен $(17,4 \%)[5]$ (табл. 2). По данным Ф. Шамира [14], у можжевельника обыкновенного в Северном Иране в эфирном масле хвои больше всего содержались следующие компоненты: сабинен (40,7\%), $\alpha$-пинен $(12,5 \%)$ и 4-терпинеол (12,3\%). С этими результатами согласуются данные Angioni B.А. и соавт. [6], которые определили, что в эфирном масле хвои можжевельника из Италии наибольшее содержание также сабинена $(61,1 \%)$ и $\alpha$-пинена $(6,4 \%)$. На основании состава эфирного масла можжевельника обыкновенного можно выделить хемотипы исследованных популяций: с доминированием в составе эфирного масла $\alpha$-пинена $[5,8-12]$ и сабинена $[6,7]$. Таким образом, качественный и количественный составы эфирного масла можжевельника характеризуются географической вариабельностью и могут быть использованы для хемосистематики.

Можжевельник обыкновенный по своей экотопической принадлежности относится к свите сосны, которая образует светлохвойные леса [15-17], однако выход и состав эфирного масла имеют свои особенности у каждого вида. У сосны обыкновенной (Pinus silvestris L.) в Красноярском крае (заповедник «Столбы») выход эфирного масла из хвои составлял $1,06 \%$ от а.с.м. [18], доля $\alpha$-пинена в нем - $31 \%, 3$-карена $8,4 \%$. В целом выход суммы монотерпеноидов эфирного масла сосны обыкновенной составил $52,5 \%$, суммы сесквитерпеноидов - 45,5\%, суммы кислородсодержащих соединений - 2\% [18]. Выход эфирного масла из свежесобранного сырья древесной зелени Pinus pumila (Pall.) Regel. в Хабаровском крае составлял $0,54 \%$. Среди идентифицированных компонентов наиболее высокая доля принадлежала $\alpha$-пинену $(26,9 \%)$, 3 -карену $(12,8 \%)$ и $\beta$-фелландрену $(10,4 \%)[19]$. Выход эфирного масла из охвоенных побегов можжевельника имеет близкие значения с выходом эфирного масла сосны, однако по содержанию фракции монотерпеноидов превосходит сосну, а по фракции сесквитерпеноидов - уступает. 
Таблица 1. Идентифицированные компоненты эфирного масла охвоенных побегов можжевельника обыкновенного

\begin{tabular}{|c|c|c|c|}
\hline № & $\mathrm{J}$ & Компонент & $\begin{array}{c}\text { Содержание от } \\
\text { цельного масла, \% }\end{array}$ \\
\hline 1 & 932 & $\beta$-туйен ( $\beta$-Thujene) & $2,37-2,43$ \\
\hline 2 & 946 & $\alpha$-пинен ( $\alpha$-Pinene) & $26,94-27,52$ \\
\hline 3 & 957 & Камфен (Camphene) & $0,22-0,23$ \\
\hline 4 & 972 & 2,6-диметил-1,3,5,7-октатетраен (2,6-dimethyl-1,3,5,7-octatetraene) & $0,25-0,26$ \\
\hline 5 & 985 & $\beta$-пинен ( $\beta$-Pinene) & $22,14-22,56$ \\
\hline 6 & 1001 & $\beta$-мирцен ( $\beta$-Myrcene) & $4,29-4,38$ \\
\hline 7 & 1020 & 3-карен (3-Carene) & $6,92-7,01$ \\
\hline 8 & 1029 & $\alpha$-терпинен ( $\alpha$-Terpinene) & $1,52-1,55$ \\
\hline 9 & 1043 & D-сильвестрен (D-Sylvestrene) & $2,16-2,20$ \\
\hline 10 & 1045 & $\beta$-фелландрен ( $\beta$-Phellandrene) & $5,69-5,75$ \\
\hline 11 & 1072 & $\gamma$-терпинен ( $\gamma$-Terpinene) & $1,16-2,80$ \\
\hline 12 & 1088 & иис- $\beta$-терпинеол (cis- $\beta$-Terpineol) & $0,27-0,31$ \\
\hline 13 & 1099 & Терпинолен (Terpinolen) & $2,96-3,00$ \\
\hline 14 & 1120 & Изовалериановая кислота (Isovaleric acid, iso pentylester) & $0,42-0,47$ \\
\hline 15 & 1126 & Масляная кислота (Butyric acid) & $0,03-0,04$ \\
\hline 16 & 1130 & $\alpha$-туйон ( $\alpha$-Thujone) & 0,19 \\
\hline 17 & 1138 & транс-изолимоненол (trans-Isolimonenol) & 0,16 \\
\hline 18 & 1144 & Валерат изо-пентенилового спирта (Valeric acid 3-methylbut-2-enil ester) & $0,25-0,30$ \\
\hline 19 & 1163 & ицс-изолимоненол (cis-Isolimonenol) & $0,37-0,40$ \\
\hline 20 & 1203 & 4-Терпинеол (4-Terpineol) & $4,71-4,74$ \\
\hline 21 & 1218 & $\alpha$-Терпинеол ( $\alpha$-terpinenol) & $0,34-0,35$ \\
\hline 22 & 1247 & Вербенил ацетат (Verbenyl acetate) & 0,23 \\
\hline 23 & 1272 & Метилцитронеллат (Metilcitronelat) & $0,16-0,17$ \\
\hline 24 & 1303 & Борнил ацетат (Bornyl acetate) & $0,17-0,18$ \\
\hline 25 & 1343 & Миртенил ацетат (Myrtenyl acetate) & $0,61-0,66$ \\
\hline 26 & 1365 & $\alpha$-терпинеол ацетат ( $\alpha$-Terpinenol acetate) & $0,62-0,66$ \\
\hline 27 & 1406 & 1 Винил, 2 изопропенил-мент-8-ен (Cyclohexan, 2.4-disopropenyl-1-methyl-1-vinyl) & $0,08-0,09$ \\
\hline 28 & 1438 & $\gamma$-элемен $(\gamma$-Elemene) & 0,03 \\
\hline 29 & 1502 & Гермакрен В (Germacrene B) & $0,10-0,12$ \\
\hline 30 & 1528 & 4,9-кадинадиен (4,9-Cadinadiene) & $0,07-0,08$ \\
\hline 31 & 1537 & Кадина-1(10),4-диен (Cadina-1(10),4-dien) & $0,13-0,14$ \\
\hline 32 & 1584 & $\alpha$-элемол ( $\alpha$-Elemol) & $0,11-0,14$ \\
\hline 33 & 1606 & Z-неролидол (Z-Nerolidol) & $0,07-0,08$ \\
\hline 34 & 1609 & Спатуленол (Spathulenol) & $0,03-0,04$ \\
\hline 35 & 1672 & n-цетан (n-Cetane) & $0,05-0,06$ \\
\hline 36 & 1675 & $\tau$-мууролол ( $\tau$-Muurolol) & $0,09-0,1$ \\
\hline 37 & 1687 & $\tau$-кадинол ( $\tau$-Cadinol) & $0,23-0,28$ \\
\hline 38 & 1731 & $\alpha$-бизаболол ( $\alpha$-Bisabolol) & $0,04-0,07$ \\
\hline 39 & 1746 & Фарнезол (Farnesol) & 0,02 \\
\hline
\end{tabular}

Таблица 2. Качественный и количественный составы эфирного масла хвои Juniperus communis, по данным литературных источников

\begin{tabular}{|c|c|c|c|c|c|c|c|c|}
\hline \multirow{2}{*}{ Компонент } & [7] & [11] & [12] & [10] & [9] & [6] & [5] & [8] \\
\hline & Литва & Канада & Хорватия & Польша & Китай & Италия & Греция & Швеция \\
\hline 1 & 2 & 3 & 4 & 5 & 6 & 7 & 8 & 9 \\
\hline$\alpha$-туйен ( $\alpha$-Thujene) & 0,1 & - & - & 0,7 & 0,2 & 2,3 & 1,7 & 0,1 \\
\hline$\beta$-туйен ( $\beta$-Thujene) & - & - & 3,6 & - & - & - & - & - \\
\hline$\alpha$-пинен ( $\alpha$-Pinene) & 27,8 & 81 & 16,9 & 70,9 & 27 & 6,4 & 41,3 & 56,8 \\
\hline$\alpha$-фенхен ( $\alpha$-Fenchene) & - & - & - & - & - & - & 0,1 & 0,3 \\
\hline Камфен (Camphene) & 0,2 & 0,6 & - & 0,5 & 1,2 & 0,04 & 0,3 & 0,6 \\
\hline Сабинен (Sabinene) & 38,7 & 0,3 & 12,1 & 7,6 & 1,2 & 61,1 & 17,4 & 0,7 \\
\hline$\beta$-пинен ( $\beta$-Pinene) & 0,5 & 5,2 & - & 2,2 & 5,2 & 0,6 & 2,1 & 4,4 \\
\hline Мирцен (Myrcene) & 2,9 & 3,4 & - & 2,5 & 2,5 & 2,6 & 2,7 & 5,2 \\
\hline$\delta$-2-карен ( $\delta$-2-Carene $)$ & - & - & - & - & - & - & 0,7 & 0,2 \\
\hline$\alpha$-фелландрен ( $\alpha$-Phellandrene) & $\operatorname{tr}$. & $\operatorname{tr}$. & - & 1,2 & - & 0,1 & 0,2 & 2,1 \\
\hline$\delta$-3-карен ( $\delta$-3-Carene) & 0,2 & 1,4 & - & 0,4 & - & - & 0,7 & 4,7 \\
\hline$\alpha$-терпинен ( $\alpha$-Terpinene) & 1,2 & - & 3,8 & - & - & 1,8 & 1,2 & tr. \\
\hline
\end{tabular}


Продолжение таблиць 2

\begin{tabular}{|c|c|c|c|c|c|c|c|c|}
\hline 1 & 2 & 3 & 4 & 5 & 6 & 7 & 8 & 9 \\
\hline$\beta$-терпинен ( $\beta$-Terpinene) & - & - & 4,3 & - & - & - & - & - \\
\hline p-цимен (p-Суmene) & 0,1 & tr. & 2,5 & 0,5 & 0,8 & 1,2 & 0,9 & 0,3 \\
\hline Лимонен (Limonene) & 2,1 & 1 & 0,2 & - & 6,2 & 2,5 & 4,2 & 5,1 \\
\hline 1,8-цинеол (1,8-Cineole) & - & - & - & - & - & - & 1,2 & - \\
\hline Борнилен (Bornylene) & - & - & 1,7 & - & - & - & - & - \\
\hline$\beta$-фелландрен ( $\beta$-Phellandrene) & 0,9 & 0,7 & 7,3 & 3,4 & - & - & 0,4 & 8,9 \\
\hline$(E)-\beta$-оцимен $((E)$ - $\beta$-Ocimene $)$ & 0,1 & - & - & - & - & - & 0,2 & 0,1 \\
\hline $\begin{array}{l}\text { Амилизобутират (Amyl } \\
\text { Isobutyrate) }\end{array}$ & - & - & - & - & - & - & - & 0,2 \\
\hline$\gamma$-терпинен ( $\gamma$-Terpinene) & 2,2 & tr. & 5,9 & 0,1 & - & 3,3 & 2,1 & tr. \\
\hline $\begin{array}{l}\text { uис-сабинен гидрат } \\
\text { (cis-Sabinene hydrate) }\end{array}$ & 0,4 & - & - & 0,1 & - & - & 0,1 & tr. \\
\hline Октен-3-ол (Octen-3-ol) & - & - & - & - & - & - & 0,1 & - \\
\hline Терпинолен (Terpinolene) & 1,5 & - & 2,9 & 0,5 & - & 1,3 & 1,2 & 1,1 \\
\hline$p$-цименен ( $p$-Сymenene) & - & - & - & 0,1 & - & - & - & - \\
\hline Цембрен (Cembrene) & - & - & 0,7 & - & - & - & - & - \\
\hline $\begin{array}{l}\text { транс-сабинен гидрат } \\
\text { (trans-Sabinene hydrate) }\end{array}$ & 0,3 & - & - & 0,1 & - & - & 0,2 & - \\
\hline Фенхон (Fenchone) & - & tr. & - & - & 0,1 & - & 0,03 & - \\
\hline$\alpha$-туйон ( $\alpha$-Thujone) & 0,4 & tr. & 0,1 & - & - & - & - & - \\
\hline$\beta$-туйон ( $\beta$-Thujone) & 0,2 & - & - & - & - & 0,3 & 0,1 & - \\
\hline $\begin{array}{l}\text { uис-р-мента-2-ен-1-ол } \\
\text { (cis-p-Mentha-2-en-1-ol) }\end{array}$ & 0,3 & - & - & - & - & - & 0,2 & tr. \\
\hline $\begin{array}{l}\text { транс-р-мента-2-ен-1-ол } \\
\text { (trans-p-Mentha-2-en-1-ol) }\end{array}$ & - & - & - & - & - & - & 0,3 & - \\
\hline $\begin{array}{l}\text { транс-вербенол } \\
\text { (trans-Verbenol) }\end{array}$ & tr. & - & - & - & - & - & - & - \\
\hline Камфора (Camphor) & 0,1 & - & 0,1 & - & 2,2 & - & 0,3 & - \\
\hline Цитронеллал (Citronellal) & - & - & - & - & - & - & 0,3 & - \\
\hline Пинокарвон (Pinocarvone) & - & - & - & - & - & - & 0,1 & - \\
\hline $\begin{array}{l}\text { Камфен гидрат } \\
\text { (Camphene hydrate) }\end{array}$ & $\operatorname{tr}$. & - & - & - & - & - & - & - \\
\hline Борнеол (Borneol) & 0,1 & - & 0,3 & - & 0,6 & - & 0,1 & 0,2 \\
\hline Терпинен-1-ол (Terpinen-1-ol) & - & - & - & - & 0,5 & - & - & - \\
\hline Терпинен-4-ол (Terpinen-4-ol) & 6,9 & 0,1 & 7,7 & 0,2 & 1,6 & 10,7 & 2,8 & 0,2 \\
\hline Юнипенен (Junipene) & - & - & - & - & 2,5 & - & - & - \\
\hline$p$-цимен-8-ol ( $p$-Cymen-8-ol) & 0,1 & - & 0,2 & - & 0,4 & - & - & tr, \\
\hline$\beta$-ионон ( $\beta$-Ionone) & - & - & 0,1 & - & - & - & - & - \\
\hline$\alpha$-терпинеол ( $\alpha$-Terpineol) & 0,6 & 0,3 & 1,1 & - & 14 & 0,5 & 0,5 & 0,2 \\
\hline$\delta$-терпинеол ( $\delta$-Terpineol) & - & - & - & - & 0,5 & - & - & - \\
\hline $\begin{array}{l}\text { uис- } \beta \text {-терпинеол } \\
\text { (cis- } \beta \text {-Terpineol) }\end{array}$ & - & - & - & - & 1,9 & - & - & - \\
\hline $\begin{array}{l}\text { транс- } \beta \text {-терпинеол } \\
\text { (trans- } \beta \text {-Terpineol) }\end{array}$ & - & - & - & - & 0,9 & 0,7 & - & - \\
\hline$\gamma$-терпинеол ( $\gamma$-Terpineol) & - & - & - & - & 1,4 & - & - & - \\
\hline $\begin{array}{l}\text { 1-p-ментен-8-ил-ацетат } \\
\text { (1-p-menthen-8-yl-acetate) }\end{array}$ & - & - & 0,9 & - & - & - & - & - \\
\hline Фелландрал (Phellandral) & - & - & 0,1 & - & - & - & - & - \\
\hline 2,4-декадиеналь (2,4-Decadienal) & - & - & 0,1 & - & - & - & - & - \\
\hline $\begin{array}{l}p \text {-мента-2,5-диен-7-ол } \\
\text { (p-menta-2,5-dien-7-ol) }\end{array}$ & - & - & 0,3 & - & - & - & - & - \\
\hline транс-карвеол (trans-Carveol) & - & - & 0,2 & - & 0,2 & - & 0,03 & - \\
\hline $\begin{array}{l}\text { транс-пинокарвеол } \\
\text { (trans-Pinocarveol) }\end{array}$ & - & - & - & - & 0,6 & - & - & - \\
\hline цис-пиперитол (cis-Piperitol) & 0,1 & - & 0,3 & - & - & - & - & - \\
\hline Додекан (Dodecane) & tr. & - & - & - & - & - & - & - \\
\hline$\beta$-цитронеллол ( $\beta$-Citronellol) & - & - & 0,1 & - & - & - & 0,2 & - \\
\hline 1,8-цинеол (1,8-Cineole) & - & - & - & - & 0,7 & - & - & - \\
\hline $\begin{array}{l}\text { транс-пиперитол } \\
\text { (trans-Piperitol) }\end{array}$ & $\operatorname{tr}$. & - & - & - & - & - & - & - \\
\hline
\end{tabular}


Продолжение таблищьь 2

\begin{tabular}{|c|c|c|c|c|c|c|c|c|}
\hline 1 & 2 & 3 & 4 & 5 & 6 & 7 & 8 & 9 \\
\hline Метил тимол (Methyl thymol) & 0,2 & - & - & - & - & - & - & - \\
\hline $\begin{array}{l}\text { Карвакрол, метиловый эфир } \\
\text { (Carvacrol, methyl ether) }\end{array}$ & 0,1 & - & 0,1 & - & - & - & - & - \\
\hline Линалоол (Linalool) & - & 0,3 & tr. & - & 10,9 & - & 0,1 & 0,1 \\
\hline $\begin{array}{l}\text { Метил цитронеллат } \\
\text { (Methyl citronellate) }\end{array}$ & tr. & 0,5 & - & - & - & - & - & - \\
\hline $\begin{array}{l}\text { Линолил ацетат } \\
\text { (Linalyl acetate) }\end{array}$ & - & - & - & - & - & - & 0,1 & - \\
\hline Борнил ацетат (Bornyl acetate) & 0,5 & 0,6 & 0,7 & 0,3 & 2,1 & 0,1 & 0,4 & 0,9 \\
\hline $\begin{array}{l}\text { транс-сабинил ацетат } \\
\text { (trans-Sabinyl acetate) }\end{array}$ & 0,1 & - & - & - & - & - & - & - \\
\hline 2-ундеканон (2-Undecanone) & 0,1 & - & - & - & - & - & - & - \\
\hline $\begin{array}{l}\text { Туйанол ацетат } \\
\text { (Thujanol acetate) }\end{array}$ & 0,1 & - & - & - & - & - & - & - \\
\hline $\begin{array}{l}\text { Терпинен-4-ол ацетат } \\
\text { (Terpinen-4-ol acetate) }\end{array}$ & 0,4 & - & - & - & - & - & - & - \\
\hline$\delta$-элемен ( $\delta$-Elemene & 0,4 & - & - & - & - & - & - & - \\
\hline $\begin{array}{l}\alpha \text {-терпинил ацетат } \\
(\alpha \text {-Terpinyl acetate) }\end{array}$ & 0,1 & - & - & - & - & 0,4 & - & - \\
\hline Миртенал (Myrtenal) & - & 0,3 & - & - & 0,5 & - & - & - \\
\hline $\begin{array}{l}\text { Цитронеллил ацетат } \\
\text { (Citronellyl acetate) }\end{array}$ & 0,1 & 0,2 & 0,1 & - & - & - & 0,5 & tr. \\
\hline $\begin{array}{l}\text { uиc-пинокарвил ацетат } \\
\text { (cis-Pinocarvyl acetate) }\end{array}$ & - & - & - & 0,2 & - & - & - & - \\
\hline $\begin{array}{l}\text { Миртенил ацетат } \\
\text { (Myrtenyl acetate) }\end{array}$ & - & 1,2 & 0,2 & - & - & 0,04 & - & tr. \\
\hline$\alpha$-копаен ( $\alpha$-Copaene) & tr. & - & - & - & - & - & 0,3 & - \\
\hline $\begin{array}{l}\text { Геранил ацетат (Geranyl } \\
\text { acetate) }\end{array}$ & tr. & - & - & - & - & - & - & - \\
\hline $\begin{array}{l}\alpha \text {-пинен оксид } \\
\alpha \text {-pinene oxide }\end{array}$ & - & - & - & - & 0,8 & - & - & - \\
\hline $\begin{array}{l}\text { транс-миртанол ацетат (trans- } \\
\text { Myrtanol acetate) }\end{array}$ & 0,5 & - & - & 0,1 & - & - & - & - \\
\hline$\beta$-элемен ( $\beta$-Elemene) & 0,4 & - & - & 0,8 & - & - & 0,1 & 0,2 \\
\hline $\begin{array}{l}\beta \text {-кариофиллен } \\
\text { ( } \beta \text {-Caryophyllene) }\end{array}$ & 0,2 & - & 0,3 & - & 0,1 & - & 1,7 & 0,7 \\
\hline Виддрен (Widdrene) & - & - & 6,4 & - & - & - & - & - \\
\hline$\beta$-гурьюнен ( $\beta$-Gurjunene) & tr. & - & - & - & - & - & - & - \\
\hline Периллен (Perillen) & - & - & - & - & 0,3 & - & - & - \\
\hline$\gamma$-элемен $(\gamma$-Elemene $)$ & 0,1 & - & 0,7 & 2,1 & - & - & - & - \\
\hline $\begin{array}{l}\text { транс-линалоол оксид } \\
\text { (trans-Linalool oxide) }\end{array}$ & - & - & - & - & 0,3 & - & - & - \\
\hline $\begin{array}{l}\text { uис-линалоол оксид } \\
\text { (cis-Linalool oxide) }\end{array}$ & - & - & - & - & 0,4 & - & - & - \\
\hline$\alpha$-гумулен ( $\alpha$-Humulene) & 0,3 & - & 0,3 & 1,3 & 0,6 & 0,1 & 1,6 & 0,5 \\
\hline$(E)-\beta$-фарнезен ((E)- $\beta$-Farnesene $)$ & tr. & - & - & - & - & - & - & - \\
\hline$\alpha$-муролен ( $\alpha$-Muurolene) & - & - & - & - & 0,4 & 0,1 & 0,2 & 0,2 \\
\hline$\gamma$-муролен ( $\gamma$-Muurolene) & 0,1 & - & - & 0,1 & 0,3 & - & 0,3 & tr. \\
\hline Гермакрен Д (Germacrene D) & 0,5 & - & - & 2,2 & - & 0,8 & 1,8 & 0,7 \\
\hline$\beta$-селинен ( $\beta$-Selinene) & tr. & - & 0,2 & 0,1 & - & - & - & - \\
\hline$\alpha$-копаен ( $\alpha$-Copaene) & - & - & - & - & 0,4 & - & - & - \\
\hline $\begin{array}{l}\text { Бициклогермакрен } \\
\text { (Bicyclogermacrene) }\end{array}$ & - & - & - & 0,4 & - & - & - & - \\
\hline Карвон (Carvone) & - & - & - & - & 0,2 & - & - & - \\
\hline$\beta$-кубебен ( $\beta$-Cubebene) & - & - & 0,7 & - & - & - & 0,03 & - \\
\hline Аристолен (Aristolene) & - & - & 0,5 & - & - & - & - & - \\
\hline$\beta$-химахален ( $\beta$-Himachalene) & - & - & 0,5 & - & - & - & - & - \\
\hline эпи-кубебол (ерi-Cubebol) & 0,2 & - & - & - & - & - & - & tr. \\
\hline Гермакрен A (Germacrene A) & - & - & - & - & - & - & - & 0,1 \\
\hline$\gamma$-кадинен ( $\gamma$-Cadinene) & 0,1 & - & - & 0,1 & 0,3 & - & 0,7 & 0,2 \\
\hline
\end{tabular}


Окончание таблиць 2

\begin{tabular}{|c|c|c|c|c|c|c|c|c|}
\hline 1 & 2 & 3 & 4 & 5 & 6 & 7 & 8 & 9 \\
\hline ס-кадинен ( $\delta$-Cadinene) & 0,7 & 0,5 & 1,4 & 0,2 & - & - & 0,9 & 0,5 \\
\hline$\varepsilon$-кадинен ( $\varepsilon$-Cadinene) & - & 0,3 & - & - & - & - & - & - \\
\hline$\alpha$-кадинен ( $\alpha$-Cadinene) & - & - & - & - & - & - & 0,1 & tr. \\
\hline Геранил ацетат (Geranyl acetate) & - & tr. & - & - & - & - & - & - \\
\hline $\begin{array}{l}\text { Цитронеллил ацетат } \\
\text { (Citronellyl butyrate) }\end{array}$ & 0,2 & - & - & - & - & - & - & - \\
\hline Миртенол (Myrtenol) & 0,1 & 0,2 & 0,2 & - & 0,4 & - & - & - \\
\hline $\begin{array}{l}\text { иис-Сесквисабинен гидрат } \\
\text { (cis-Sesquisabinene hydrate) }\end{array}$ & 0,1 & - & 1,1 & - & - & - & - & - \\
\hline $\begin{array}{l}\text { транс-сабинен гидрат } \\
\text { (trans-sabinene hydrate) }\end{array}$ & - & - & 0,6 & - & - & - & - & - \\
\hline Элемол (Elemol) & 0,4 & tr. & 0,1 & - & - & - & - & tr. \\
\hline $\begin{array}{l}\text { Капнеллан-8-он } \\
\text { (Capnellane-8-on) }\end{array}$ & - & - & 0,2 & - & - & - & - & - \\
\hline$\alpha$-цедрол ( $\alpha$-Cedrol) & - & - & 0,3 & - & - & - & - & - \\
\hline Гермакрен Б (Germacrene В) & 0,4 & - & - & - & - & - & - & 0,3 \\
\hline $\begin{array}{l}\text { ГермакренД-4-ол } \\
\text { (Germacrene D-4-ol) }\end{array}$ & 0,2 & - & - & 0,2 & - & - & - & 0,8 \\
\hline Спатуленол (Spathulenol) & 0,6 & - & 0,4 & 0,1 & - & - & - & $\operatorname{tr}$ \\
\hline $\begin{array}{l}\text { Кариофиллен оксид } \\
\text { (Caryophyllene oxide) }\end{array}$ & tr. & - & - & - & - & 0,1 & - & $\operatorname{tr}$. \\
\hline $\begin{array}{l}\text { Этил додеканот } \\
\text { (Ethyl dodecanoate) }\end{array}$ & 0,1 & - & - & - & - & - & - & - \\
\hline 1-эnи-кубенол (1-ерi-Cubenol) & 0,4 & - & - & - & - & - & - & $\operatorname{tr}$ \\
\hline 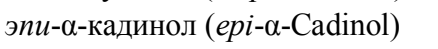 & 0,4 & - & - & - & 0,1 & - & - & $\operatorname{tr}$. \\
\hline эпи- $\alpha$-муролол (ерi- $\alpha$-Muurolol) & 0,5 & - & - & - & - & - & - & 0,4 \\
\hline$\alpha$-муролол ( $\alpha$-Muurolol) & 0,4 & - & - & - & - & - & - & $\operatorname{tr}$ \\
\hline Т-муролол (T-Muurolol) & - & - & 0,3 & - & - & - & - & - \\
\hline$\alpha$-кадинол ( $\alpha$-Cadinol) & 1,1 & - & - & - & - & - & 0,7 & 0,5 \\
\hline Т-кадинол (T-Cadinol) & - & - & 0,3 & - & - & - & 0,8 & - \\
\hline Шиобунол (Shyobunol) & - & - & - & - & - & - & - & 0,7 \\
\hline Фарнезол (Farnesol) & - & 0,1 & - & - & - & - & - & - \\
\hline (E)-неролидол ((E)-Nerolidol) & - & - & - & - & - & - & 1 & - \\
\hline $\begin{array}{l}\text { 14-гидрокси-9-эпи- } \beta \text { - } \\
\text { кариофиллен (14-hudroxy-9- } \\
\text { epi- } \beta \text {-Caryophyllene) }\end{array}$ & 0,2 & - & - & - & - & - & - & - \\
\hline $\begin{array}{l}\text { Эудесм-7(11)-ен-4-ол } \\
\text { (Eudesm-7(11)-en-4-ol) }\end{array}$ & 0,1 & - & - & - & - & - & - & - \\
\hline $\begin{array}{l}\text { (Z)-3-гексенил нонаноат } \\
((Z)-3 \text {-Hexenyl nonanoate) }\end{array}$ & - & - & - & - & 0,5 & - & - & - \\
\hline $\begin{array}{l}\text { Изокариофиллен оксид } \\
\text { (Isocaryophyllene oxide) }\end{array}$ & - & - & - & - & 0,8 & - & - & - \\
\hline $\begin{array}{l}\text { Гумулен оксид (Humulene } \\
\text { oxide) }\end{array}$ & - & - & - & - & - & - & 0,7 & - \\
\hline $\begin{array}{l}\text { Кариофиллен оксид } \\
\text { (Caryophyllene oxide) }\end{array}$ & - & - & - & - & 2,6 & - & 0,8 & - \\
\hline Total & 98,5 & 98,2 & 90,6 & 99,7 & 95,5 & 97,7 & 96 & 98,6 \\
\hline
\end{tabular}

\section{Заключение}

Таким образом, выход эфирного масла в мае у можжевельника обыкновенного, произрастающего на северо-востоке европейской части России, составил 0,8\%. В его составе преобладает фракция монотерпенов. Из данной фракции наибольшее содержание принадлежит $\alpha$-пинену, $\beta$-пинену, 3 -карену и $\beta$-фелландрену. Эфирное масло можжевельника обыкновенного характеризуется географической изменчивостью.

\section{Список литературы}

1. Adams R.P., Pandey R.N. Analysis of Juniperus communis and its varieties based on DNA fingerprinting // Biochem. Syst. Ecol. 2003. N31. Pp. 1271-1278.

2. Лесная энциклопедия. М., 1986. Т. 2. 631 с. 
3. Berta F. Occurrence and composition of essential oils in species of the genus Juniperus // Folia Dendrologica. 1993. Vol. 20. Pp. 301-312.

4. Marongiu B., Porcedda S., Piras A., Sanna G., Murreddu M., Loddo R. Extraction of Juniperus communis L. ssp nana Willd. essential oil by supercritical carbon dioxide // Flavour and Fragrance Journal. 2006. Vol. 21. Pp. 148-154.

5. Chatzopoulou P.S., Katsiotis S.T. Study of the essential oil from Juniperus communis 'berries' (cones) growing wild in Greece // Planta Medica. 1993. Vol. 59. Pp. 554-556.

6. Angioni B.A., Russo M.T., Coroneo V., Dessi S., Cabras P. Chemical composition of the essential oils of Juniperus from ripe and unripe berries and leaves and their antimicrobial activity // Agricultural and Food Cehemistry. 2003. Vol. 51. Pp. 3073-3078.

7. Butkiene, R., Nivinskiene O., Mockute D. Two chemotypes of essential oils produced by the same Juniperus communis L. growing wild in Lithuania // Chemija. 2009. Vol. 20. N3. Pp. 195-201.

8. Adams R.P., Beauchamp P.S., Dev V., Bathala R.M. The leaf essential oils of Juniperus communis L. varieties in North America and the NMR and MS data for Isoabienol // Journal of Essential Oil Research. 2010. Vol. 22 , N23. Pp. 23-28.

9. Carroll J.F., Tabanca N., Kramer M., Elejalde N.M., Wedge D.E., Bernier U.R., Coy M., Becnel J.J., Demirci B., Husnu Can Baser K., Zhang J., Zhang S. Essential oils of Cupressus funebris, Juniperus communis, and J. chinensis (Cupressaceae) as repellents against ticks (Acari: Ixodidae) and mosquitoes (Diptera: Cuclicidae) and as toxicants against mosquitoes // Journal of Vector Ecology. 2011. Vol. 36, N2. Pp. 258-268.

10. Filipowicz N., Madanecki P., Golebiowski M., Stepnowski P., Ochocka J.R. HS-SPME/GC Analysis reveals the population variability of terpene contents in Juniperus communis needles // Chemistry \& Biodiversity. 2009. Vol. 6. Pp. 2290-2301.

11. Rudloff E. von, Sood V.K. Gas-liquid chromatography of terpenes. Part. XVIII. The volatile oil of the leaves of Juniperus communis L. // Canadian Journal of Chemistry, 1969. Vol. 47, N11. Pp. 2081-2086.

12. Mastelic J., Milos M., Kustrak D., Radonic A. Essential oil and glycosidically bound volatile compounds from the needlesof common juniper (Juniperus communis L.) // Croat Chemical Acta. 2000. Vol. 73, N2. Pp. 585-593.

13. Государственная фармакопея СССР. ХІ изд. Вып. 1. М., 1987. 335 с.

14. Shahmir F., Ahmadi L., Mirza M., Korori S.A. Secretory elements of needles and berries of Juniperus communis L. ssp. communis and its volatile constituentsv // Flavour and Fragrance Journal. 2003. Vol. 18. Pp. 425-428.

15. Харламова С.В. Внутрипопуляционная изменчивость можжевельника обыкновенного // Экология и генетика популяций. Йошкар-Ола, 1998. С. 314-316.

16. Барзут О.С. Эколого-географическая изменчивость можжевельника обыкновенного : автореф. дис. ... канд. биол. наук. Архангельск, 2007. 18 c.

17. Бекмансуров М.В., Горохова Т.А. О структуре популяций Juniperus communis L. в условиях Марийского Заволжья // Принципы и способы сохранения биоразнообразия : материалы III Всеросс. науч. конф. ЙошкарОла, 2008. С. 308-309.

18. Сотникова О.В., Степень Р.А. Эфирные масла сосны как индикатор загрязнения среды // Химия растительного сырья. 2001. №1. С. 79-84.

19. Стародубов А.В., Домрачев Д.В., Ткачев А.В. Состав эфирного масла кедрового стланика (Pinus pumila) из Хабаровского края // Химия растительного сырья. 2010. №1. С. 81-86.

Поступило в редакичию 13 января 2016 г.

После переработки 16 марта 2016 г. 
Gerling N.V.*, Punegov V.V., Gruzdev I.V. COMPONENT COMPOSITION OF ESSENTIAL OIL JUNIPERUS COMMUNIS (JUNIPERUS COMMUNIS L.) UNDER THE CANOPY OF SPRUCE FORESTS IN THE EUROPEAN NORTH-EAST RUSSIA

Institute of Biology, Komi Science Centre, ul. Kommunisticheskaja, 28, GSP-2, Syktyvkar, Komi Republic, 167982

(Russia),e-mail: Gerling1@rambler.ru

Essential oil of Juniperus, grown under the canopy of spruce bilberry-sphagnum, is a liquid of light yellow color. The content of essential oil in shoots Juniperus was $0,81 \%$. 39 components were identified in essential oil. Mass fraction of identified components accounted for $86 \%$ of total composition essential oil. Monoterpenes in identified components occupy $90,5 \%$, $0,4 \%$ sesquiterpenes, alcohols $7,5 \%$ and ethers to $1,6 \%$. As part of essential oil of Juniperus communis 96 components have a concentration of less than $1 \%, 10$ components from $1-5 \%, 4$ components - more than $5 \%$. Higher concentrations noted for components such as $\alpha$-pinene $27,2 \%, \beta$-pinene $22,4 \%, 3$-carene $7 \%$ and $\beta$-phellandrene $5,7 \%$. Component composition of essential oil of Juniperus communis is characterized by geographical variability. The yield of essential oil of juniper shoots have similar values with the yield of essential oil of pine (Pinus pumila (Rall.) Regel.) in the Khabarovsk region, but the content of fractions monoterpenoids superior pine and faction sesquiterpenoids inferior.

Keywords: Juniperus communis, shoot, essential oil.

\section{References}

1. Adams R.P., Pandey R.N. Biochem. Syst. Ecol. 2003, no. 31, pp. 1271-1278.

2. Lesnaia entsiklopediia. [Wood encyclopedia]. Moscow, 1986, vol. 2, 631 p. (in Russ.).

3. Berta F. Folia Dendrologica. 1993, vol. 20, pp. 301-312.

4. Marongiu B., Porcedda S., Piras A., Sanna G., Murreddu M., Loddo R. Flavour and Fragrance Journal, 2006, vol. 21, pp. 148-154.

5. Chatzopoulou P.S., Katsiotis S.T. Planta Medica. 1993, vol. 59, pp. 554-556.

6. Angioni, Barra A., Russo M.T., Coroneo V., Dessi S., Cabras P. Agricultural and Food Cehemistry, 2003, vol. 51, pp. 3073-3078.

7. Butkiene, R., Nivinskiene O., Mockute D. Chemija, 2009, vol. 20, no. 3, pp. 195-201.

8. Adams R.P., Beauchamp P.S., Dev V., Bathala R.M. Journal of Essential Oil Research, 2010, vol. 22, no. 23, pp. $23-28$.

9. Carroll J.F., Tabanca N., Kramer M., Elejalde N.M., Wedge D.E., Bernier U.R., Coy M., Becnel J.J., Demirci B., Husnu Can Baser K., Zhang J., Zhang S. Journal of Vector Ecology, 2011, vol. 36, no. 2, pp. 258-268.

10. Filipowicz N., Madanecki P., Golebiowski M., Stepnowski P., Ochocka J.R. Chemistry \& Biodiversity, 2009, vol. 6, pp. 2290-2301.

11. von Rudloff E., Sood V.K. Canadian Journal of Chemistry, 1969, vol. 47, no. 11, pp. 2081-2086.

12. Mastelic J., Milos M., Kustrak D., Radonic A. Croat Chemical Acta. 2000, vol. 73, no. 2, pp. 585-593.

13. Gosudarstvennaia farmakopeia SSSR. [State Pharmacopoeia of the USSR], vol. 1. Moscow, 1987, 335 p. (in Russ.).

14. Shahmir F., Ahmadi L., Mirza M., Korori S.A. Flavour and Fragrance Journal, 2003, vol. 18, pp. 425-428.

15. Kharlamova S.V. Ekologiia i genetika populiatsii. Ioshkar-Ola, 1998, pp. 314-316. (in Russ.).

16. Barzut O.S. Ekologo-geograficheskaia izmenchivost' mozhzhevel'nika obyknovennogo: Avtoref. diss. kand. biol. nauk. [Ecological and geographical variability of Juniperus: author. dis. ... cand. biol. sciences]. Arkhangel'sk, 2007, 18 p. (in Russ.).

17. Bekmansurov M.V., Gorokhova T.A. Printsipy i sposoby sokhraneniia bioraznoobraziia: Materialy III Vserossiiskoi nauchnoi konferentsii. [Principles and methods for the conservation of biodiversity: materials III All-Russian scientific conference.]. Ioshkar-Ola, 2008, pp. 308-309. (in Russ.).

18. Sotnikova O.V., Stepen' R.A. Khimiia rastitel'nogo syr'ia, 2001, no. 1, pp. 79-84. (in Russ.).

19. Starodubov A.V., Domrachev D.V., Tkachev A.V. Khimiia rastitel'nogo syr'ia, 2010, no. 1, pp. 81-86. (in Russ.).

Received January 13, 2016

Revised March 16, 2016

\footnotetext{
* Corresponding author.
} 